\title{
In vitro ROOTING OF TENERA HYBRID OIL PALM (Elaeis guineensis Jacq.) PLANTS ${ }^{1}$
}

\author{
Marlúcia Souza Souza Pádua ${ }^{2 *}$, Raíssa Silveira Santos ${ }^{3}$, Luciano Vilela Paiva ${ }^{4}$, Vanessa Cristina Stein ${ }^{5}$ and \\ Luciano Coutinho Silva ${ }^{6}$

\footnotetext{
${ }^{1}$ Received on 16.06.2016 accepted for publication on 12.09.2017.

${ }^{2}$ Universidade Federal de Lavras, Doutoranda em Biotecnologia Vegetal, Lavras, Minas Gerais - Brasil. E-mail: $<$ marluciabio@yahoo.com.br>.

${ }^{3}$ Universidade Federal de Lavras, Graduanda em Agronomia, Lavras, Minas Gerais - Brasil. E-mail: <raissa_silveira93@hotmail.com>.

${ }^{4}$ Universidade Federal de Lavras, Departamento de Química, Lavras, Minas Gerais - Brasil. E-mail: <luciano@dqi.ufla.br>.

${ }^{5}$ Universidade Federal de São João Del-Rei, Campus Centro-Oeste Dona Lindu, Divinópolis, Minas Gerais - Brasil. E-mail: <vanessastein@ufsj.edu.br>.

${ }^{6}$ Universidade Federal da Paraíba, Departamento de Biologia Celular e Molecular, João Pessoa, Paraíba - Brasil. E-mail: $<$ lucoutsilva@yahoo.com.br>.

*Corresponding author.
}

\begin{abstract}
Oil palm is a woody monocot of economic importance due to high oil production from its fruits. Currently, the conventional method most used to propagate oil palm is seed germination, but success is limited by long time requirements and low germination percentage. An alternative for large-scale propagation of oil palm is the biotechnological technique of somatic embryogenesis. The rooting of plants germinated from somatic embryos is a difficult step, yet it is of great importance for later acclimatization and success in propagation. The aim of this study was to evaluate the effect of the auxins indole acetic acid (IAA) and indole butyric acid (IBA) on the rooting of somatic embryos of Tenera hybrid oil palm. Plants obtained by somatic embryogenesis were inoculated in modified MS medium with $10 \%$ sucrose and $0.6 \%$ agar and supplemented with IAA or IBA at concentrations of $5 \mu \mathrm{M}, 10 \mu \mathrm{M}$, and $15 \mu \mathrm{M}$, and the absence of growth regulators. After 120 days, the presence of roots, root type, length of the longest root, number of roots, number of leaves, and shoot length were analyzed. Growth regulators were favorable to rooting; plants cultivated with IBA growth regulator at $15 \mu \mathrm{M}$ showed higher rooting percentage (87\%) and better results for the parameters of number of roots (1.33) and shoot length (9.83).
\end{abstract}

Keywords: Tissue Culture; Indole acetic acid; Indole butyric acid.

\section{ENRAIZAMENTO In vitro DE PLANTAS DE DENDEZEIRO (Elaeis guineensis Jacq.) HÍBRIDO TENERA}

\begin{abstract}
RESUMO-O dendezeiro é uma monocotiledônea, lenhosa e oleaginosa de elevada importância econômica, devido à alta produção de óleo por seus frutos. A germinação das sementes é, atualmente, o método convencional mais utilizado para a propagação do dendezeiro, porém, o sucesso por meio dessa via é limitado pela demora e a baixa porcentagem de germinação. Uma alternativa para a propagação em larga escala do dendezeiroé a técnica biotecnológica de embriogênese somática, mas o enraizamento das plantas germinadas a partir dos embriões somáticos é uma etapa dificil e de grande importância para posterior aclimatização e sucesso na propagação. Este trabalho foi realizado com o objetivo de avaliar o efeito das auxinas ácido indol acético (AIA) e ácido indol-butírico (AIB) no enraizamento de embriões somáticos de dendezeiro híbrido Tenera. Plantas obtidas via embriogênese somática foram inoculadas em meio MS modificado, com 10\% de sacarose e 0, $6 \%$ de ágar e suplementado com AIA ou AIB, nas concentrações $5 \mu \mathrm{M}, 10 \mu \mathrm{M}, 15 \mu \mathrm{M}$ e na ausência de regulador de crescimento. Depois de 120 dias foram analisados os parâmetros presença de raiz, tipo de raiz, comprimento da maior raiz, número de folhas e comprimento da parte aérea. A presença de reguladores de crescimento foi favorável ao enraizamento, tendo as plantas cultivadas com o regulador de crescimento AIB na concentração de 15 MM apresentado maior porcentagem de enraizamento $(87 \%)$ e melhores resultados para os parâmetros número de raízes $(1,33)$ e comprimento da parte aérea $(9,83)$.
\end{abstract}

Palavras-Chave: Cultura de Tecidos; Ácido Indol Acético; Ácido indol butírico. 


\section{INTRODUCTION}

Oil palm (Elaeis gineensis Jacq.) is a oleic monocotyledonous, that has a long productive life cycle, approximately 25 years, cultivated in humid tropical regions (Morcillo et al., 2007). Oil palm oil is used in the food, cosmetics, pharmaceutical and biofuel industries (Boari, 2008, Natura, 2010).

The agronomic importance of oil palm is a result of its high capacity to produce oil, reaching 5-7 tons/ ha under optimum conditions. With more than 8 million cultivated hectares in the world, oil palm is the second largest global source of vegetable oil after soybean (Rajesh et al., 2003; Lin et al., 2009).

Oil palm has a single shoot apical meristem, and this biological trait makes vegetative propagation of the species impossible through conventional cultivation of cuttings, a reality that limits production of seedlings on a commercial scale (Martine et al., 2009). Thus, it becomes necessary to seek technical alternatives, such as plant tissue cultures by somatic embryogenesis (Morcillo et al., 2007), which allows clones to be obtained on a commercial scale. This technique also favors largescale production of elite genotypes obtained through conventional breeding programs (Xavier et al., 2009; Roowi et al., 2010).

Somatic embryos are formed without any fertilization event and are genetically identical to the original tissues and can be used in studies of genetic transformation, of molecular, regulator, and morphogenetic events. They also allow large-scale production of synthetic plants and seeds, which have the advantages of ease of handling and transport, long-term storage potential, uniform production, and the potential for automating the entire production process (Pathi et al., 2013).

During in vitro cultivation and germination of somatic embryos, a crucial step for woody species is rooting. This step is necessary for oil palm because studies confirm the need for in vitro rooting for success in the later stage of acclimatization. Oil palm plants rooted in vitro had an $85 \%$ survival rate during the acclimatization phase, in contrast with only $40 \%$ of those not rooted in vitro (Pádua et al., 2014).

The use of different classes of plant regulators and changes in the composition of other components of the nutrient media can assist in obtaining more promising results, especially in root formation, which is one of the limiting phases of in vitro cultivation of forest species (Curti and Reiniger, 2014).

In vitro rooting of plants can be induced by plant regulators of the auxin class, the most cited being indole acetic acid (IAA) and indole butyric acid (IBA). The presence of the IAA auxin in the culture medium can favor the root system, greater presence of secondary roots, lower formation of calluses, and good shoot development (Radmann, 2002). However, for woody species that root with difficulty, the IBA auxin has been successfully used in most studies, as, for example, in date palm (Qaddoury and Amssa, 2003), physic nut (Toppo and Sing, 2012), eucalyptus (Almeida et al., 2007; Brondani et al., 2014), and golden shower tree (Curti and Reiniger, 2014).

Most of the propagations works with oil palm are focused on indirect somatic embryogenesis, but the limitation of this technique is the plants transference to ex vitro environment due to low roots formation, necessary to provide better survival during acclimatization. Balzon et al., (2013) transferred to ex vitro condition, only the rotted oil palm plants, which were approximately 6-8.

In this context, the aim of this study was to evaluate the effect of the growth regulators IAA and IBA on in vitro rhizogenesis of plants derived from somatic embryos of oil palm (Elaeis guineensis Jacq).

\section{MATERIALS AND METHODS}

\subsection{Plant material}

The experiment was conducted in the Central Molecular Biology Laboratory of the Universidade Federal de Lavras in Lavras, MG, Brazil.

Plants of the Tenera hybrid of Elaeis guineensis Jacq., obtained through somatic embryogenesis, were used, with an approximate height of $4 \mathrm{~cm}$. They were kept in an MS (Murashige and Skoog, 1962) culture medium which consisted of half the concentrations of the salts, supplemented with 2,57 $\mu \mathrm{M}$ IAA, $1,11 \mu \mathrm{M}$ BAP, $20 \mathrm{~g}, \mathrm{~L}^{-1}$ inositol, and vitamins (10 mg.L $\mathrm{L}^{-1}$ thiamin, $1 \mathrm{mg} . \mathrm{L}^{-1}$ pyridoxine, $1 \mathrm{mg} . \mathrm{L}^{-1}$ nicotinic acid, and $1 \mathrm{mg} . \mathrm{L}^{-1}$ glycine). Maintained in a growroom at $26 \pm 2^{\circ} \mathrm{C}$ and 16 -hour photoperiod.

\subsection{Rooting}

For rooting, the plants were inoculated in a modified MS culture medium, with the addition of 10 g.L $\mathrm{L}^{-1}$ sucrose and $0.6 \%$ agar, supplemented with IAA or IBA at the concentrations of 5,10 , and $15 \mu \mathrm{M}$, and the control

Revista Árvore. 2017;41(4):e410414

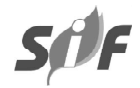


treatment was composed of the base medium, without the addition of growth regulator. The $\mathrm{pH}$ values of all the culture media were adjusted to $5.7 \pm 0.1$ before sterilization at $121^{\circ} \mathrm{C}$ for 20 minutes. The IAA growth regulator was filter sterilized and added to the culture medium after autoclaving, and the IBA growth regulator was introduced in the medium before autoclaving.

The plants were subcultured every 30 days for 120 days and kept in a growroom at a temperature of $26 \pm 2{ }^{\circ} \mathrm{C}$ with a 16 -hour photoperiod.

A completely randomized experimental design was used in a $2 \times 4$ factorial arrangement, with the first factor composed of the two growth regulators (IBA and IAA) and the second, by the different concentrations $(0,5,10$, and $15 \mu \mathrm{M})$. The experiment was composed of three replications, each one consisting of five explants. Evaluation was carried out after 120 days considering the parameters: presence of roots, root type (thick or thin), number of roots, length of the longest root, number of leaves, and shoot length.

\subsection{Statistics}

The data were subjected to analysis of variance and the means were compared by the Tukey test and by polynomial regression, both at $5 \%$ probability. Analyses were performed by the computational program SISVAR (Ferreira, 2011).

\section{RESULTS}

All the treatments showed root formation on the oil palm seedlings; nevertheless, the culture medium containing the IAA and IBA auxins provided significantly higher rooting percentages compared to the control treatment. The IBA auxin at the highest concentration tested, $15 \mu \mathrm{M}$, exhibited a higher rooting percentage, $87 \%$, differing from the treatments with lower concentrations (5 and $10 \mu \mathrm{M}$ ), which exhibited $27 \%$ and $20 \%$ rooting, respectively. The treatment with 15 $\mu \mathrm{M}$ of IBA also exhibited a higher result compared to the IAA auxin at the 5,10 , and $15 \mu \mathrm{M}$ concentrations, which had percentages of $47 \%, 53 \%$, and $53 \%$, respectively. In the control treatment, that is, culture medium without the addition of growth regulators, there was a low percentage (13\%) of roots (Figure 1A).

The plants cultivated in culture medium containing the IAA auxin at the concentration of $10 \mu \mathrm{M}$ showed the best results for the longest root variable, with a
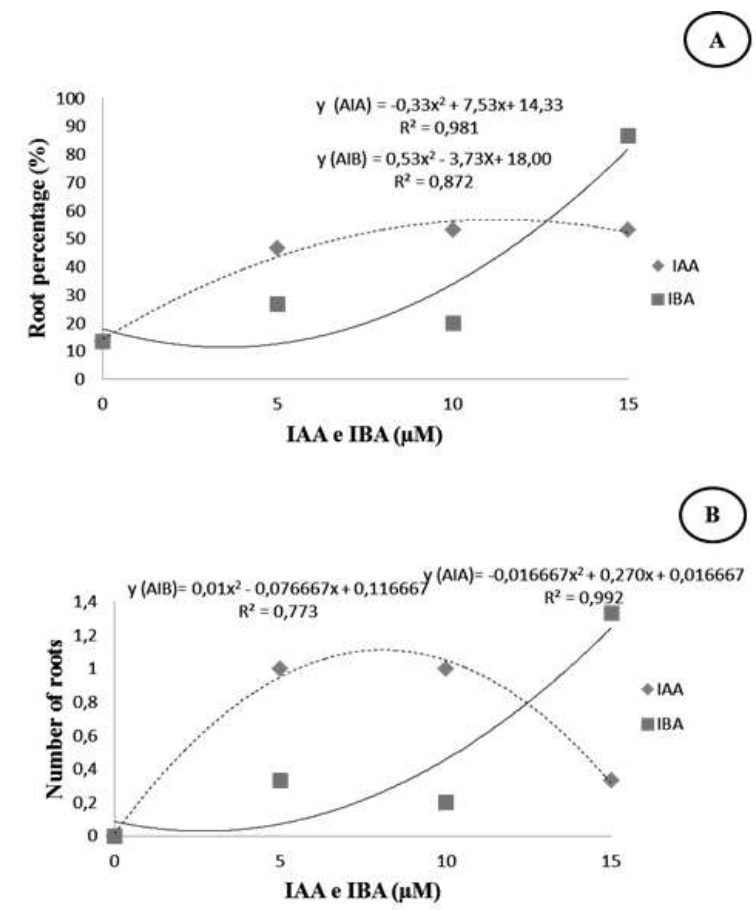

Figure 1 - Root percentage (A) and number of roots (B) of seedlings of the Tenera hybrid of Elaeis guineensis Jacq., cultivated under different concentrations of IAA and IBA, during 120 days.

Figura 1 - Porcentagem de raízes $(A)$ e número de raízes (B) de plântulas de Elaeis guineensis Jacq., híbrido Tenera, cultivadas em diferentes concentrações de AIA e AIB, durante 120 dias.

mean of $2.3 \mathrm{~cm}$, and the concentration of $15 \mu \mathrm{M}$ provided a mean of $1.9 \mathrm{~cm}$ (Figure 2A). In relation to IBA, the highest concentration tested $(15 \mu \mathrm{M})$ induced the longest root length $(1.7 \mathrm{~cm})$ (Figure $2 \mathrm{~A})$.

For shoot length, the treatment with IAA did not show significant difference, and the IBA treatment showed positive linear results with the increase in concentration; and both regulators showed significant positive results in relation to the control (absence of auxins). The seedlings cultivated in $15 \mu \mathrm{M}$ of IBA had $10 \mathrm{~cm}$ shoot length, and, in this treatment also, the longest and most branched roots were observed in relation to the other concentrations of IBA (Figure 3A).

The IAA and IBA growth regulators promoted a higher percentage of formation of thick and branched adventitious roots, and the concentrations of $10 \mu \mathrm{M}$ and $15 \mu \mathrm{M}$ de IBA provided for greater formation of lateral roots. 

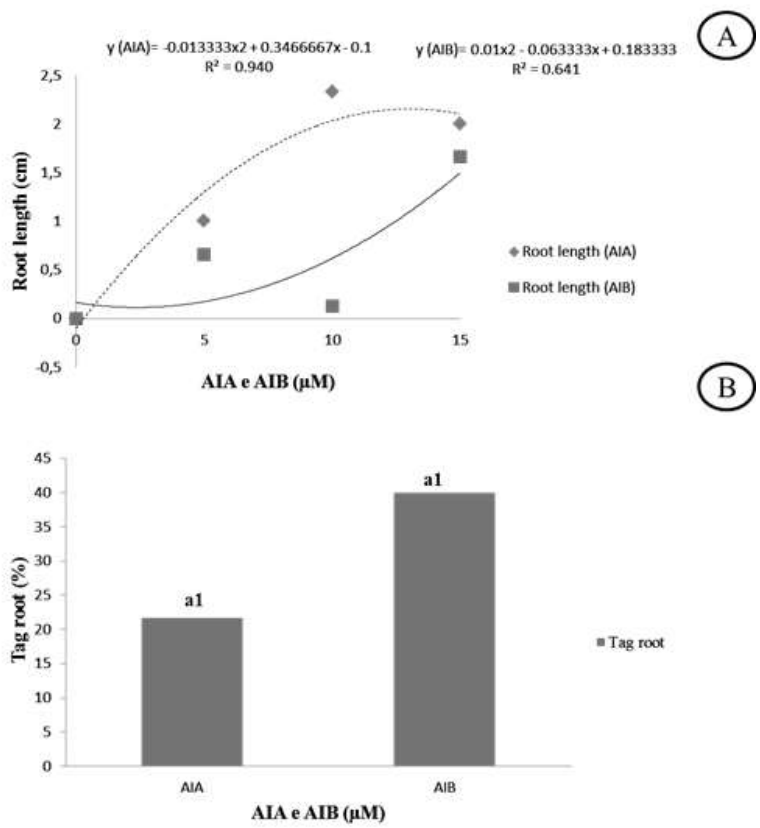

Figure 2 - Root length (A) and root morphology (B) of seedlings of the Tenera hybrid of Elaeis guineensis Jacq., cultivated under different concentrations of IAA and IBA, during 120 days. In the comparision of each characteristics, columns with same letter have bars not differ by Tukey test at $5 \%$ probability.

Figura 2 - Comprimento da raiz (A) e morfologia da raiz (B) de plântulas de Elaeis guineenses Jacq., hibrido Tenera, cultivadas em diferentes concentrações de AIA e AIB, durante 120 dias. Na comparação de cada uma das características, barras com a mesma letra não diferem entre si pelo teste de Tukey a $5 \%$ de probabilidade.

In regard to number of leaves, there was no difference between the auxin sources. The absence of auxin in the culture medium promoted the greatest number of leaves (7.7), and a decrease in the number of leaves was observed with the increase in IAA or IBA concentration (Figure 3B).

\section{DISCUSSION}

In plants that regenerate roots spontaneously, such as oil palm, which showed $13 \%$ rooting in the culture medium without IAA or IBA, the endogenous auxins produced in the shoot tip are transported in a polar, basipetal manner and act as a trigger to activate rooting.

In these plants, the application of exogenous auxin usually strongly increases the number of roots
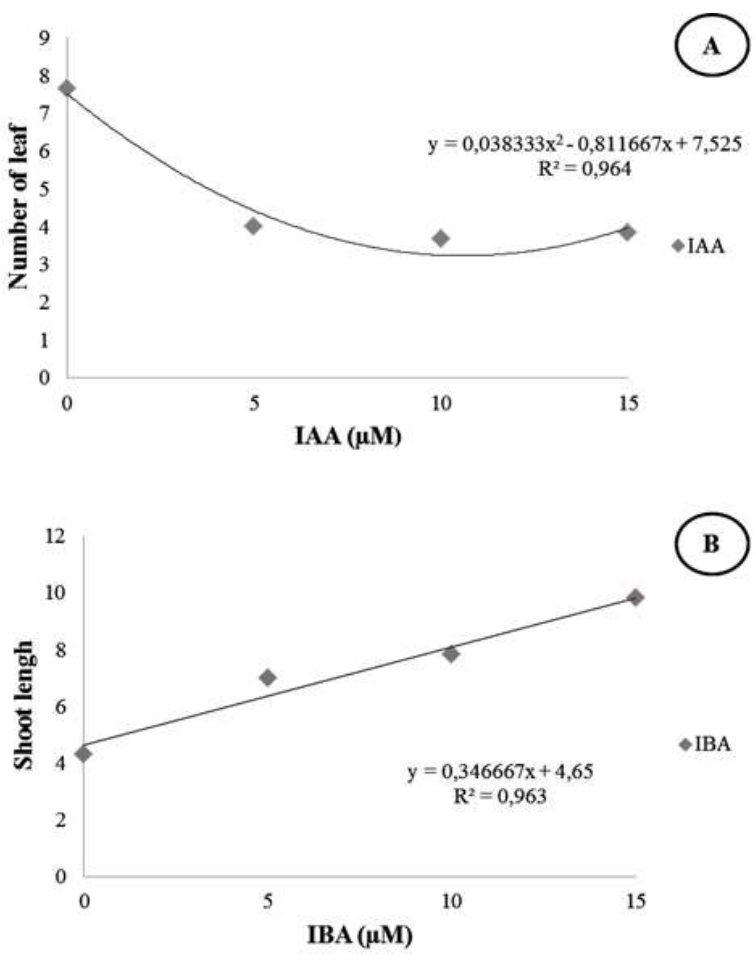

Figure 3 - Effect of IBA and IAA during in vitro rooting of the Tenera hybrid of oil palm Elaeis guineensis Jacq. plants, in relation to number of leaves per explant (A) ad to shoot length (B).

Figura 3 -Efeito do AIB e AIA, durante o enraizamento in vitro de plantas de dendezeiro Elaeis guineensis Jacq. híbrido Tenera, com relação ao número de folhas por explante $(A)$ e ao comprimento da parte aérea $(B)$.

regenerated (Klerk et al., 1999), as was observed in the treatment with the highest concentration of IBA, which showed $87 \%$ rooting. These data corroborate studies with Cedrela odorata L., which exhibits good in vitro rooting capacity, even in the absence of auxin, but the presence of IBA in the culture medium significantly increases the percentage, the number, and the length of roots (Millán-Orozco et al., 2011). A higher percentage of rooted plants in a culture medium with $5 \mu \mathrm{M}$ of IBA was also observed in studies with Olea europaea L. cultivars, with $75 \%$ rooting (Radmann et al., 2002).

For oil palm, the IAA and IBA growth regulators provided significantly higher rooting percentages compared to the control treatment, and the IBA auxin provided the highest rooting percentage, $87 \%$. The IBA auxin is one of the most used for rooting of woody

Revista Árvore. 2017;41(4):e410414 
species, probably due to chemical stability, the broader spectrum of action, and the lower phytotoxicity caused to the explant compared to other growth regulators (George et al., 2008; Latsague et al., 2009; Uribe et al., 2012).

In contrast, the IAA growth regulator has less stability and, consequently, greater degradation and lower absorption rate in relation to IBA (Erig and Schuch, 2004). This may explain the lower rooting rate (53\%) of oil palm plants in this study when subjected to the lowest IAA concentration tested. The lower stability and, consequently, greater degradation are related to IAA capacity of bonding to other molecules in the plant, producing conjugates and losing its activity, and also being subject to degradation by the IAA oxidase enzyme (Ross, 1992; Taiz and Zeiger, 2013).

In addition, photo-oxidation of IAA in the culture medium is faster than that of IBA because approximately $50 \%$ is degraded in the first 24 hours, whereas only $10 \%$ of the IBA is photo-oxidized in the same period (Nissen and Sutter, 1990).

Results contrary to this study were observed in root induction in Croton sonderianus Muell, in which the IBA growth regulator at the concentration of $5 \mu \mathrm{M}$ was more effective, compared to the concentration of $5 \mu \mathrm{M}$ of IAA (Erig and Schuch, 2004). At this same concentration, it induced high rooting percentages (85\%) in Jatropha curcas L. (Toppo and Sing, 2012).

The decrease in rooting observed with the increase in the concentration of the IAA growth regulator may be related to the question of the concentrations of growth regulators having an optimal level for promoting rooting, and when this concentration is raised, it may not be significant for an increase in the percentage of rooting or it may compromise rhizogenesis (Ugraiah et al., 2011). Thus, it is important to establish an ideal concentration for root induction for each species (Fachinello et al., 1995; Mansseri-Lamrioui et al., 2011). In Ficus carica L. plants, the IBA growth regulator at the concentration of $25 \mu \mathrm{M}$ led to the best rooting percentage and the largest number of roots (Barbosa et al., 2007).

Konan et al. (2007) observed that the effect of the ANA growth regulator at the concentration of $1 \mathrm{mg} . \mathrm{L}^{-1}$ varied according to the genotype oil palm. The lineage obtained from different explants responded different in plant rooting.
The association of ANA, auxins, with a BAP, cytokinin, did not improved the rooting, only the shots formation, suggesting that the rooting step should be performed separately from the shoot production, in order not to interfere with rooting (Thuzar et al., 2011).

The size and architecture of the root system determine the ability of the plant to access water and nutrients, and these are factors that limit growth and, thus, production in many agricultural ecosystems (Price et al., 1997). Plants with larger and more branched roots, such as those observed in the treatment with $10 \mu \mathrm{M}$ and $15 \mu \mathrm{M}$ of IBA, have greater ability in competing for nutrients and surviving under nutritional deficiency conditions in the soil (Coque and Gallais, 2006). For shoot length the IBA treatment showed positive linear results. The seedlings cultivated in $15 \mu \mathrm{M}$ of IBA showed highest $(10 \mathrm{~cm})$ shoot length, and, also the longest and most branched roots in relation to the other concentrations of IBA (Figure 3A). Moreover, the plants, cultivated on AIA, showed lower rooting, and low leaves number, showing the o roots system is important to access water and nutrients important to develop leaves.

Results similar to those of this study, which found introduction of IBA favorable to shoot length and rooting percentage, were obtained in studies on Carica papaya L., in which $5.92 \mu \mathrm{M}$ of the IBA benefit both rooting percentage and shoot growth (Schmildt et al., 2010). In Eucalyptus cloeziana F. Muell the concentration of IBA in in vitro cultivation influenced acclimatization of plants, and the best concentration for root induction corresponded to the best concentration during plant acclimatization (Almeida et al., 2007).

Leaf emergence in the shoot apical meristem is dependent on the dynamic movement of auxin around the meristem. Its transport occur from the newly-formed leaf to the connected stem and is accompanied by differentiation of the leaf midrib and its vascular connection with the stem (Müller and Leyser, 2011). Shoot apexes are determined and able to grow, as long as necessary nutritional and light conditions are supplied.

In rooting of microcuttings of Morus sp., using IBA in the culture medium, statistical differences were not observed in leaf emergence for the control group (without auxin), as observed in this study (Augusto et al., 2006).

Revista Árvore. 2017;41(4):e410414 


\section{CONCLUSION}

Growth regulators are effective in root induction under the different concentrations tested. The IBA Auxin $(15 \mu \mathrm{M})$ had greater rooting rates $(87 \%)$ and is most recommended based on the results of this study for root induction in Elaeis guineensis Jacq. Tenera hybrid oil palm.

\section{REFERENCES}

Almeida FD, Xavier A, Dias JMM, Paiva HN. Eficiência das auxinas (AIB e ANA) no enraizamento de miniestacas de clones de Eucalyptus cloeziana F. Muell. Revista Árvore.2007;31(3):455-63.

Augusto CSS, Biasi LA, Telles CA. Enraizamento e aclimatização de plantas micropropagadas de amoreira-preta CV Brazos. Revista Brasileira de Fruticultura. 2006;28(3):473-6.

Balzon TA, Luis, ZG, Scherwinski-Pereira JE. New approaches to improve the efficiency of somatic embryogenesis in oil palm (Elaeis guineensis Jacq.) from mature zygotic embryos. InVitro Cell Dev. Biol, Plant. 2013, 49: 41-50.

Barbosa W, Pio R, Feldberg NP, Chagas EA, Ferraz R, Veiga FA. Enraizamento de estacas lenhosas de pereira tratadas com AIB e mantidas em ambiente de estufa tipo B.O.D e de telado. Revista Brasileira de Fruticultura. 2007;29(3):589-94.

Boari AJ. Estudos realizados sobre o amarelecimento fatal do dendezeiro (Elaeis guineensis Jacq.)Belém: Embrapa Amazônia Oriental; 2008. 59p. (Documentos, 348)

Brondani GE, Baccarin FJB, Bergonci T, Gonçalves AN, Almeida M. Miniestaquia de Eucalyptus benthanii: Efeito do genótipo, AIB, zinco, boro e coletas de brotações. Revista Cerne. 2014;20(1):147-56.

Coque M, Gallais A Genomic regions involved in response to grain yield selection at high and low nitrogen fertilization in maize. Theoretical and Applied Genetics. 2006;112(7):1205-20.

Curti AR, Reiniger LRS. In vitro rhizogenes in Peltophorum dubium: the effect of different culture media. Ciência Rural. 2014;44(2):314-20.
Erig AC, Schuch MW. In vitro rooting of quince cvMC as rootstock for pear and acclimatization of the rooted microcuttings.Ciência Rural. 2004;34(5):1443-9.

Fachinello JC, Hoffmann A, Nachtigal JC, Kersten E, Fortes GRL. Propagação de plantas frutíferas de clima temperado. $2^{\mathrm{a}}$ ed. Pelotas: UFPel; 1995.

Ferreira DF. SISVAR: um programa para análise e ensino de estatística. Revista Ciência e Agrotecnologia. 2011;35(6):1039-42.

George EF, Hall MA, De Klerk, GJ. Plant propagation by tissue culture. $3^{\text {rd }}$. ed. Dordrecht: Springer; 2008.

Konan EE, Durand-Gasselin T, Kouadio JY, Flori A, Riva A. A modeling approach of the in vitro conversion of oil palm (Elaeis guineensis) somatic embryos. Plant Cell Tissue and Organ Culture. 2005;84:99-112.

Klerk GJ, Krieken WVD, Jong JC. The formation of adventitious roots: new concepts, new possibilities. In Vitro Cellular \& Developmental Biology Plant. 1999;35(3):189-99.

Latsague M, Sáez P, Yáñez, J. Efecto del ácido indolbutírico en la capacidad rizogénica de estacas de Eucryphia glutinosa. Bosque. 2009;30(2):102-5.

Lin, HC, Morillo F, Dussert F, Tranchant-Dubreuil C, Tregear JW, Tranbarger TJ. Transcriptome analysis during somatic em- bryogenesis of the tropical monocot Elaeis guineensis: evidence for conserved gene functions in early development. Plant Molecular Biology. 2009;70(1-2):173-92.

Martine MB, Laurent KK, Pierre BJ, Eugène KK, Hilaire KT, Justin KY. Effect of storage and heat treatments on the germination of oil palm (Elaeis guineensis Jacq.) seed. African Journal Agricultural Research. 2009;4(10):931-7.

Mansseri-Lamrioui A, Bonaly J, Yakoub-Bougdal S, Allili N, Gana-Kebbouche S. Proliferation and rooting of wild cherry: The influence of cytokinin and auxin types and their concentration. African Journal of Biotechnology. 2011;10(43):43:8613-24.

Revista Árvore. 2017;41(4):e410414

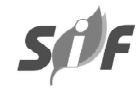


Millán-Orozco L, Corredoira E, San-José MDC. In vitro rhizogenesis: histoanatomy of Cedrela odorata (Meliaceae) microcuttings. Revista Biologia Tropical. 2011;59(1):447-53.

Morcillo F, Gallard A, Pillot M, Jouannic S, Aberlenc-Bertossi F, Collin M et al. EgAP2-1, an AINTEGUMENTA-like (AIL) gene expressed in meristematic and proli ferating tissues of embryos in oil palm. Planta. 2007;226(6):1353-62.

Müller D, Leyser O. Auxin cytokinin and the control of shoot branching. Annals of Botany. 2011;107(7):1203-12.

Murashige T, Skoog FA. A revised medium for rapid growth and bioassays with tobacco tissue cultures. Plant Physiology. 1962;15:473-9.

Nissen JS, Sutter EG. Stability of AIA and AIB in nutrient medium of several tissue culture procedures. HortScience. 1990;25(3):800-2.

Pádua MS, Paiva LV, Silva LGT, Silva LC, Stein C. In vitro development and acclimatization of dendezeiro (Elaeis guineenisis)Revista Árvore. 2014;38(6):1095-102.

Pathi KM, Tula S, Tuteja N. High frequency regeneration via direct somatic embryogenesis and efficient Agrobacterium-mediated genetic transformation of tobacco. Plant Signaling \& Behavior. 2013;8(6):24354.

Price AH, Tomos AD, Virk DS. Genetic dissection of root growth in rice (Oryza sativa L.) I: A hydroponic screen. Theoretical Applied Genetics. 1997;95(1/2):132-42.

Qaddoury A, Amssa M. Action de l'acide índole butyrique sur l'enracinement des jeunes rejets de Palmier dattier. Acta Botanica Gallica: Botany Letters. 2003;150(2):213-22.

Radmann EB, Fachinello JC, Peters JA. Efeito de auxinas e condições de cultivo no enraizamento in vitro de porta-enxertos de macieira ' $\mathrm{M}-9$ '.

Revista Brasileira de Fruticultura. 2002;24(3):624-8.

Rajesh MK, RadhA E, Karun A, Parthasarathy VA. Plant regeneration from embryo-derived callus of oil palm - the effect of exogenous polyamines. Plant Cell Tissue and Organ Culture. 2003;75(1):41-7.

Roowi, SH, Ho, CL, Alwee, SS, Abdullah, MO, Napis, S. Isolation and characterization of differentially expressed transcripts from the suspension cells of oil palm (Elaeis guineensis Jacq.) in response to different concentration of auxins. Molecular Biotechnology. 2010;46(1):1-19.

Ross CW. Hormones and growth regulators: auxins and gibberellins. In: Salisbury FB, Ross CW editors. Plant physiology. $4^{\text {th }}$. ed. Belmond: Wadsworth; 1992. p.357-77.

Schmildt ER, Amaral JAT, Schimildt O, Coelho RI, Rabello WS, Filho SMl. Níveis de ácido indol butírico (AIB) no enraizamento in vitro de microestacas de mamoeiro 'Tainung 01'. Acta Scientiarum - Agronomy. 2010;32(1):125-9.

Taiz L, Zeiger E. Fisiologia vegetal. $5^{\mathrm{a}}$.ed. Porto Alegre: Artmed; 2013. 820p.

Toppo DD, Singh G, Purshottam DK, Misra P. Improved in vitro rooting and acclimatization of Jatropha curcas plantlets. Biomass and Bioenergy. 2012;4(4):42-6.

Thuzar M, Vanavichit A. Efficient and rapid plant regeneration of oil palm zygotic embryos cv'Tenera' through somatic embryogenesis. Acta Physiologiae Plantarum. 2011;33(1):123-8.

Ugraiah A, Sreelatha R, Reddy K, Rajasekhar K, Rani SS, Karuppusamy S et al. In vitro shoot multiplication and conservation of Caralluma bhupenderiana Sarkaria - an endangered medicinal plant from South India. African Journal of Biotechnology. 2011;10(46):9328-36.

Uribe KME, Ulloa J, Delaveau C, Sáez K, Munõz F, Cartes P. Influencia de las auxinas sobre el enraizamiento in vitro de microtallos de Nothofagus glauca (Phil.) Krasser. Gayana Botânica. 2012;69(1):105-12.

Xavier A, Wendling L, Silva RL. Silvicultura clonal: princípios e técnicas. Viçosa, MG: Universidade Federal de Viçosa; 2009. 272p. 